\section{RISUS - Journal on Innovation and SUstainability ISSN 2179-3565 \\ wark (s)

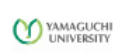

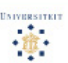 \\ 委 \\ (1)}

RISUS - Journal on Innovation and Sustainability Volume 6, número 2 - 2015

ISSN: 2179-3565

Editor Científico: Arnoldo José de Hoyos Guevara Editora Assistente: Nara Pamplona Macedo Avaliação: Melhores práticas editoriais da ANPAD

\title{
Comparative Analysis of the Science and Technology Parks of the US Universities and a Selected Developing Country
}

\author{
Alireza Aslani ${ }^{1}$, Hossein Eftekhari ${ }^{2}$, Mehdi Didari ${ }^{2}$ \\ ${ }^{1}$ Industrial Management Department, University of Vaasa, \\ Finland, Faculty of New Sciences and Technology, University of \\ Tehran; ${ }^{2}$ Interdisciplinary department, University of Tehran, Iran \\ E-mail: alireza.aslani@ut.ac.ir
}

\begin{abstract}
Science and technology parks (STP) are as the main linkage between university and industry in order to develop and commercialize innovations and new products/services. A STP is an area where innovation is a key and supports university, industry and even government collaborations to speed the development of high tech-economic and advancing knowledge. They provide a variety of shared resources such as incubators, collaboration activities, uninterruptible power supply, reception and security, science and technology corridor, management offices, restaurants, bank, internal transportation, entertainment and sports facilities to bring the potential ideas and products/services in the market and industry to improve the community prosperity.

This research reviews the STPs located in the US universities in order to have a comparative analysis with a STP located in the developing countries. Our case is the STP of the University of Tehran in Iran. Although the STO of University of Tehran is working with more than 10 years' experience, however, there are noticeable gaps between the achievements and potentials and targets based on the assessment indicators. Therefore, comparative studies with successful cases help to cover such gap. Our research also presents an innovative framework in order to better performance of STP of the University of Tehran.
\end{abstract}

Keywords: Science and Technology Park; Innovation; Commercialization; Developing countries; US universities; University of tehran 


\section{INTRODUCTION}

Science and Technology Park (STP) is an American phenomenon with the age of more than 70 years old. It is a response to the entrepreneurs from the universities or research centers who have innovative ideas and are willing to commercialize them. Science and technology companies are encouraged to nurture ideas, innovate and grow, with the facilities, infrastructure, and services located to the STP ${ }^{[1]}$. Therefore, STP is source of entrepreneurship and economic competitiveness that provides a location in which universities, companies, and government cooperate and collaborate. They enhance Technological development and related commercialization $^{[2]}$.

The Stanford Research Park is the first STP located in the California state introduced in 1951. This park is the result of Fredrich Terman's idea that is known as "grandfather of Silicon Valley". Castells \& Hall (1994), know STP as "Technopol", "Technology Park", "Science Cities", "Techno Police" and "technological-industrial complex"[3].

\section{The scope of science and technology parks}

At last the author provides evidence of internalization where a company analyzes the economThere are different definition and scope for STP as follows: - "Research parks" as the areas with number of public/private research laboratories.

- "University-industry park" that combine facilities of universities and industry to increase their interactions. There are research parks joined by universities.

- "Industrial parks" where are particular areas where the density of high-tech industries/ companies is high. Many small and large cities of the world dedicated the areas to this purpose.

- "Incubators" designed in smaller scales with fewer resources to encourage entrepreneurs in the commercialization of scientific and technological ideas.

- "Science cities" located in the urban areas included: universities, industry, research laboratories, etc. an example is "Tsukuba" in Japan.

"Science Region" are Larger areas such as Silicon Valley in the United States that reasons such as close to universities and research centers, communication centers, and low cost facilities at the beginning of their formation, research laboratories and industry to increase the density of the top (high-tech) are encouraged companies to locate in that area.

In addition to the mentioned cases, developments in telecommunications led to the formation of Proceedings of the 11th International Conference on Innovation \& Management "virtual park" as a collection of parks, universities, research centers, suppliers and professors in the frame of network elements collaborate in reality ${ }^{[4]}$

\section{An introduction to science and technology parks in Iran}

Around thirty STPs are working in Iran that the age of some of them is more than 15 years. There are two tips of STPs in Iran, namely STPs of the Universities such as STP of the University of Tehran (UT), and STP of the providence, such as STP parks of Fars. Some provenance like Tehran has three STPs located in different geographical areas. The idea of STP of UT was established in 2001. The park is located in one of the main campus of the UT in the business area of the Tehran. There are more than two hundred knowledge-based companies in the fields of oil and gas, IT, nano technology, medicine, marketing, and etc. are in the STP of the UT. Two 
competitive advantages of this park are the brand, that is a part of UT as the best university in Iran, and geographical situation which is located in the downtown.

Based on the statistics published in August 2014, there are 231 companies/cores located in the STP of the UT with 270 percent growth compared with 2008 (62 companies). These companies/cores are divided into two main categories: Technology companies ( $43.5 \%$ of total in 2008 and $60.4 \%$ in 2014 ) and technology cores (56.6\% of total in 2008 and $39.4 \%$ in 2014). On the other hand, around 1800 job opportunities have created by companies located in the STP of UT around five times more than 2008 (Figure 1). Indeed, the wealth created by the companies has been increased three times more than 2008. These statics show that the STP of the UT is a young STP with a wide range of opportunities and growth potentials. However, the park has faced with many challenges that affect the process of servicing to the knowledge-based companies. In other words, the indicators show that the performance of STP has not been based on the expectations and satisfactions of the beneficiaries.

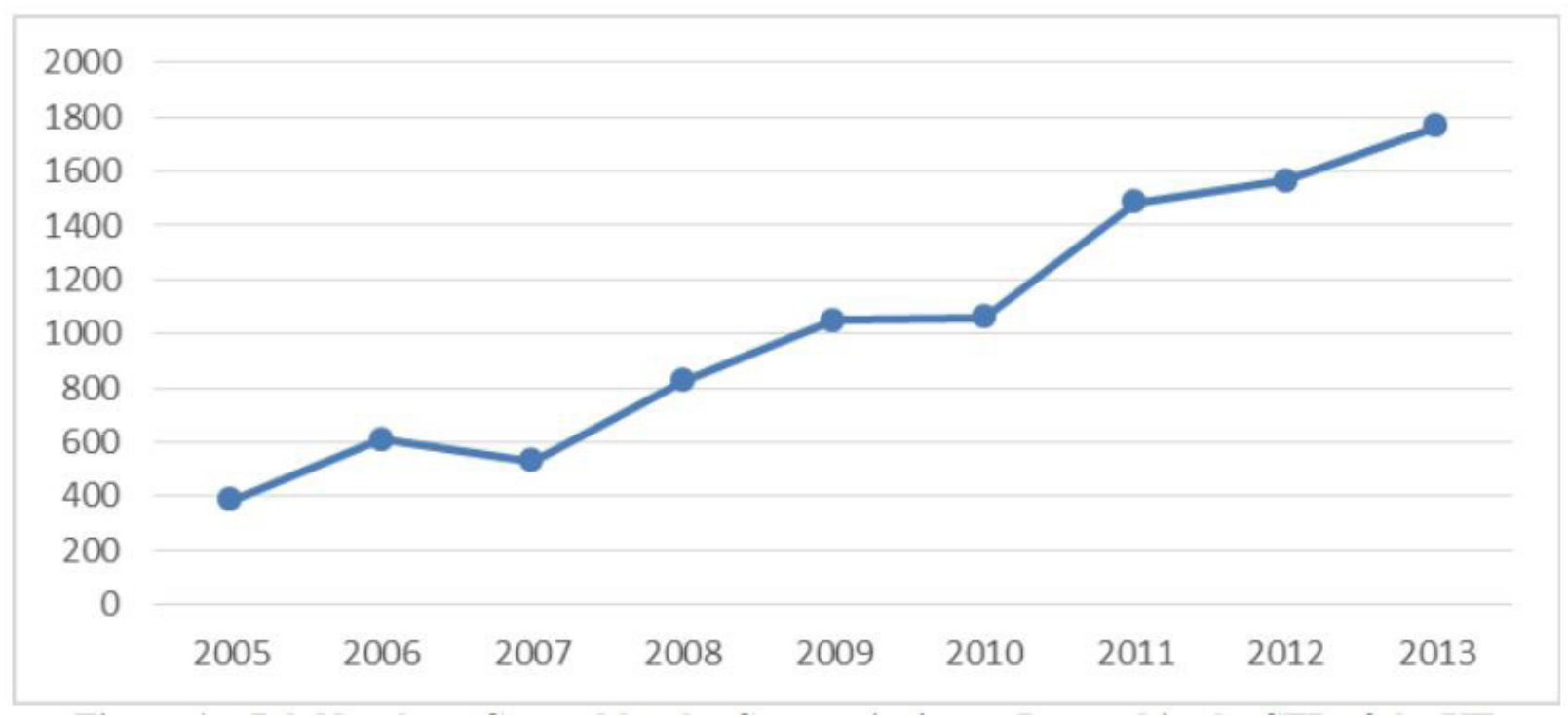

Figure 1 Job Numbers Created by the Companies/cores Located in the STP of the UT

\section{Main challenges of the STP of the UT}

\subsection{Infrastructural facilities and sources}

One of the most important problems of the STP of the UT is the lack of suitable spaces for allocating the companies and cores. Due to the aim of the STPs to provide the required infrastructure of knowledge based companies, one of the most important infrastructure is shared or separate professional laboratories. On the other hand, due to the governmental nature of the STP of the UT, the park has limitations from budget and manpower aspects that affect work flows and servicing to the companies.

\subsection{Lack of clear priorities}

Providing appropriate services in order to convert knowledge into wealth, commercialization of research achievements, and technology networking between industry and academia are the main issues in the mission of the STP of the UT. Due to the resource limitations 
such as budget and infrastructures, it is impossible to consider to all aspects of the mission to persuade the beneficiaries from the knowledge-based companies to etc. on the other hand, it is not possible if the STP tries to work on almost all business areas. For example, the infrastructures and facilities required to enable companies in the field of information technology are quite different with the oil and gas industries. Therefore, successful STPs have not worked in all field of knowledge that Silicon Valley in the US with focusing on information technology is an example.

\subsection{High authority of the government in managing of STPs}

All STPs in Iran are under belongings of the government. Therefore, the decision and policy making process at the STPs are governmental. In addition the governmental borocraties, paying too much attention to the interests of the governmental sector is another problem that such managing brings to the STPs. Due to the private nature of the companies located in the STP, this brings difficulties for making fast and flexible decisions.

\section{An overview on some successful Science and Technology parks in the US 4.1 Silicon Valley \& Stanford Research Park}

It is the first scientific park known based on the current definitions. In fact, information technology revolution has been one of the main drivers of Silicon Valley growth and success. Through 1993 to 1997, more than 45 percent of American industrial growth in the computer and semiconductor industry were in this region. Silicon Valley culture in a way that encourages the formation of new technological companies. The main components of this culture are:

\subsection{Freedom Experience: This factor encourages managers to encourage the creativity}

Acceptance of rapid change: This component allows the business owners revision their works patterns and think about new products before losing their market share.

Creating entrepreneurs: The Silicon Valley is one of the successful parks that extracts entrepreneurs who have worked in the companies and create wealth from their creative ideas and innovations.

Agile systems: including motivating potential customers by offering free samples of new products, offering the product in the right time and place, etc.

Investment in young firms: Successful companies invest in new technology firms (technological entrepreneurship) and maintain their leading. Companies like INTEL could reducing the R\&D costs with archives on new technologies.

Overall, researchers have identified six main factors of Silicon Valley success: access on skilled manpower, access on existing infrastructure, access on venture capitals, occupational mobility, communication networks, and spin-offs.

\subsection{Research Triangle Park}

In 1959, the nonprofit foundation titled "Research Triangle Foundation" was formed to initial activities began to attract capital from the public aids. This park is the result of cooperation between universities of Duke, North Carolina and North Carolina State universities with support from the central government, the governor, and industrialists, could provide a model for the science parks in world.

Research Triangle Park is made up of three parts:

A tax-deductible nonprofit benefit that is owned by the University Park, which is the foundation of their profitable. 
The Research Triangle Institute as a nonprofit research organization has been established completely independent.

Notable features of the park include:

Connect the park with three universities

Park-like atmosphere

Development and infrastructure provision by government

Research Triangle Park with an area of 3200 hectares in the center of a triangle of three cities "Durham", "Rally", "Chapel Hill" is located in North Carolina. Residential areas, educational centers and other facilities located in three cities and the research institutes have been established in the park. In this area, there are cheap and beautiful environment and pleasant homes, attract and recruit researchers has facilitated.

\subsection{Central Florida Research Park}

Central Florida Research Park, which is located near the University of Central Florida is a university-affiliated research park and created in 1975. The park aims to coordinate and completes victory of the rules that it has created "Encourage and promote research activities using the resources of higher education institutions, private companies that are engaged in applied and pure research. The goal of this park is creating an "industrial university community". Companies located in this park participates in the joint research projects with faculty members as consultants, and the hiring of part-time students, senior experts working under the internship program with the University of Central Florida. The companies can also use library, computer center and laboratories by contract with university. Most of the companies in the Park are large state-dependent companies and they aim to expand product lines and operations of the respective units. The financial resources of these companies and funded by venture capital resources. According to studies, companies believe that the park's financial obligations, lack of marketing researches, and lack of marketing plans are the major impediments to the growth of Central Florida Research Park

\section{RESEARCH METHODOLOGY}

This research is a qualitative research. First the authors review and analysis the situation of the STP of the UT based on the important indicators to identify the gaps and weaknesses. After that, a comparative analysis with the STPs of the US universities has been done to improve the work and performance of the STP of the UT. Therefore, the research is an applied research from the research purpose, and is a descriptive research from the research method. To enrich the analysis and their innovative framework, the authors has also interviewed with different professionals and experts working in the STPs. This helps the researchers assure about the validity and reliability of their research.

\section{Analyzing the STP of the UT with the STPs of the US universities}

This section analyzes the STP of the UT with selected STPs in the US based on the fifteen indicators. Table 1 shows and compares the indicators of the STP of the UT with the selected STPS in the US: 
Table 1 Comparing the STPs of the UT and US

\begin{tabular}{|c|c|c|c|c|}
\hline Indicator & Silicon Valley & $\begin{array}{l}\text { The Research } \\
\text { Triangle Park }\end{array}$ & $\begin{array}{l}\text { Central Florida } \\
\text { Research Park }\end{array}$ & $\begin{array}{c}\text { STP of the Universi- } \\
\text { ty of Tehran }\end{array}$ \\
\hline Age & More than 80 years & More than 70 years & More than 30 years & More than 10 years \\
\hline $\begin{array}{l}\text { Type of companies } \\
\text { located in parks }\end{array}$ & $\begin{array}{l}\text { Mostly IT, electronic, } \\
\text { defense, and military }\end{array}$ & $\begin{array}{c}\text { Mostly } \\
\text { Microelectronic, } \\
\text { Telecommunication, } \\
\text { Chemical material, } \\
\text { Biotechnology, } \\
\text { pharmacology, and } \\
\text { environment }\end{array}$ & $\begin{array}{l}\text { IT, Laser, } \\
\text { behavioral scien- } \\
\text { ce, oceanographic } \\
\text { equipment }\end{array}$ & $\begin{array}{l}\text { In all fields such as Oil } \\
\& \text { Gas, IT, agricultural }\end{array}$ \\
\hline $\begin{array}{c}\text { Close corporation } \\
\text { with the university of }\end{array}$ & Stanford & $\begin{array}{c}\text { Duke and North } \\
\text { Carolina State }\end{array}$ & $\begin{array}{l}\text { University of Central } \\
\text { Florida } \\
\end{array}$ & University of Tehran \\
\hline $\begin{array}{l}\text { Biggest companies } \\
\text { that have at least an } \\
\text { office located in the } \\
\text { park }\end{array}$ & $\begin{array}{c}\text { apple, Cisco, eBay, } \\
\text { Facebook, google, } \\
\text { Microsoft }\end{array}$ & $\begin{array}{l}\text { IBM, fortune 500, } \\
\text { Mitsubishi }\end{array}$ & $\begin{array}{l}\text { Boeing Corporation } \\
\text {,CiscoSystems Inc., } \\
\text { Hewlett-Packard } \\
\text { Company } \\
\end{array}$ & Petroleum companies \\
\hline Number of companies & More than 170 & More than 170 & 178 & 105 \\
\hline Number employee & 23000 & 49000 & 10000 & 1800 \\
\hline Facilities & $\begin{array}{l}\text { Using the services of } \\
\text { research companies } \\
\text { of Stanford university, } \\
\text { absorbing financial } \\
\text { facilities from private } \\
\text { and public sectors, } \\
\text { simplifying the legal } \\
\text { services for knowled- } \\
\text { ge based companies, } \\
\text { prov iding tax facilities } \\
\text { for companies by go- } \\
\text { vernment, providing } \\
\text { venture capital }\end{array}$ & $\begin{array}{l}\text { Providing } \\
\text { incubator facilities } \\
\text { for new companies, } \\
\text { absorbing requisite } \\
\text { finance for compa- } \\
\text { nies, Tax Exemption, } \\
\text { inexpensive houses } \\
\text { for researchers }\end{array}$ & $\begin{array}{l}\text { Public finances, ven- } \\
\text { ture capital, providing } \\
\text { services for compa- } \\
\text { nies located in park by } \\
\text { the institutes related } \\
\text { to the university, using } \\
\text { the libraries, labora- } \\
\text { tories and computer } \\
\text { centers; consulting } \\
\text { with professors, } \\
\text { using trainees by the } \\
\text { companies located in } \\
\text { the park }\end{array}$ & $\begin{array}{c}\text { Loan, Providing } \\
\text { incubator facilities } \\
\text { for new companies, } \\
\text { guarantee facilities to } \\
\text { the companies in the } \\
\text { contracts with public } \\
\text { sector }\end{array}$ \\
\hline Infrastructures & $\begin{array}{l}\text { Lease land Electronic } \\
\text { laboratories; provi- } \\
\text { ding rapid manufactu- } \\
\text { ring and Prototyping } \\
\text { Laboratory, land, } \\
\text { venture capital, } \\
\text { information exchange } \\
\text { networks }\end{array}$ & $\begin{array}{l}\text { Lease land for compa- } \\
\text { nies, federal labora- } \\
\text { tories, infrastructure } \\
\text { development by } \\
\text { support of central go- } \\
\text { vernment; communi- } \\
\text { cation infrastructures } \\
\text { such as international } \\
\text { airport, railroads, and } \\
\text { high-way networks } \\
\end{array}$ & $\begin{array}{l}\text { Lease land, using the } \\
\text { services of large labo- } \\
\text { ratories in the field of } \\
\text { simulation and instru- } \\
\text { mentation related to } \\
\text { USA defense sector }\end{array}$ & Lease land \\
\hline Websites & $\begin{array}{l}\text { http://www.siliconval- } \\
\text { leyindex.org }\end{array}$ & $\begin{array}{l}\text { http://www.rtp.org/ } \\
\text { about-rtp, http:// } \\
\text { www.learnnc.org/ } \\
\text { Ip/editions/nchist- } \\
\text {-recent/6177 }\end{array}$ & $\begin{array}{c}\text { http://www.cfrp. } \\
\text { org/property- } \\
\text {-info, http://www. } \\
\text { floridatrend.com/ } \\
\text { article/16849/univer- } \\
\text { sity-research-parks-in- } \\
\text {-florida?page=3 }\end{array}$ & http://www.utstp.ir/ \\
\hline Spin-off & Very high & Very high & Very high & Low \\
\hline
\end{tabular}


As shown in the Table 1, the STP of the UT is younger than other three parks that can be considered as an advantage because it can uses the experiments and successful efforts of the other parks. On the other hand, one of the major weaknesses of the STP of the UT is unclear priorities. In other words, while the case studies in the US have specific fields, the STP of the UT is the place of all types of the companies. When an area is well known because of an area of science, like Silicon Valley with IT and electronic industries, this brings more innovation and joint projects and thereby wealth for the companies. As an example, when a STP has more than 30-40 companies work in an industry, the possibility of successful efforts such as technology clusters, venture capitals, etc. will be increased.

Comparing the number of companies and employees in our cases show that while the number of companies in the STP of the UT is quite good and similar with the US parks, however, the number of employees is not good. This means the number of successful companies that work in the medium or big scales with big market is not comparable with the US parks. On the other hand, the facilities provided by the UT Park such as research centers, laboratories etc. are very limit in comparison with the US parks. For instance the service provided by the STP of the UT is limited to the land lease, but in the US parks a variety of services can be found. On the other hand, lack of some units/ department in headquarters of the STP of the UT such as commercialization unit in order to support the companies to help sell their products/services can be found. In other words, the STP parks should focus on the whole chain of innovation, starting from idea (technology core) to commercialization of the product/service.

Researches show that the main actors of innovation process are: governments, private companies in particular Knowledge-Based Companies, universities and research institutes, and investors and advisors.

These actors are in contact with each other that their interactions improve economic growth and innovation process. None of these players cannot alone guarantee growth and innovation. While companies require knowledge, it mostly is produced at the University. At the same time, both companies and universities need the governmental supports and capitals of the investors. In other words, to commercialize the university researchers, close corporation with companies and investors is necessary. Figure 2 shows the innovative model of success for managing and improving the performance of STP.

According to the figure, STPs can become the center of intelligent information management, information flow and communication process between government, academia and industry. STP with the intermediation of knowledge and information in the areas of technology, market, investment, human resources and public facilities and professional actors can help in the following areas: business growth and development, creation of new companies, commercialization of ideas, and facilitation and innovation management for national and regional strategies. These assistances are eventually led to the formation of creating knowledge-based industries and consequently, increases revenue, occupation and economic growth. 


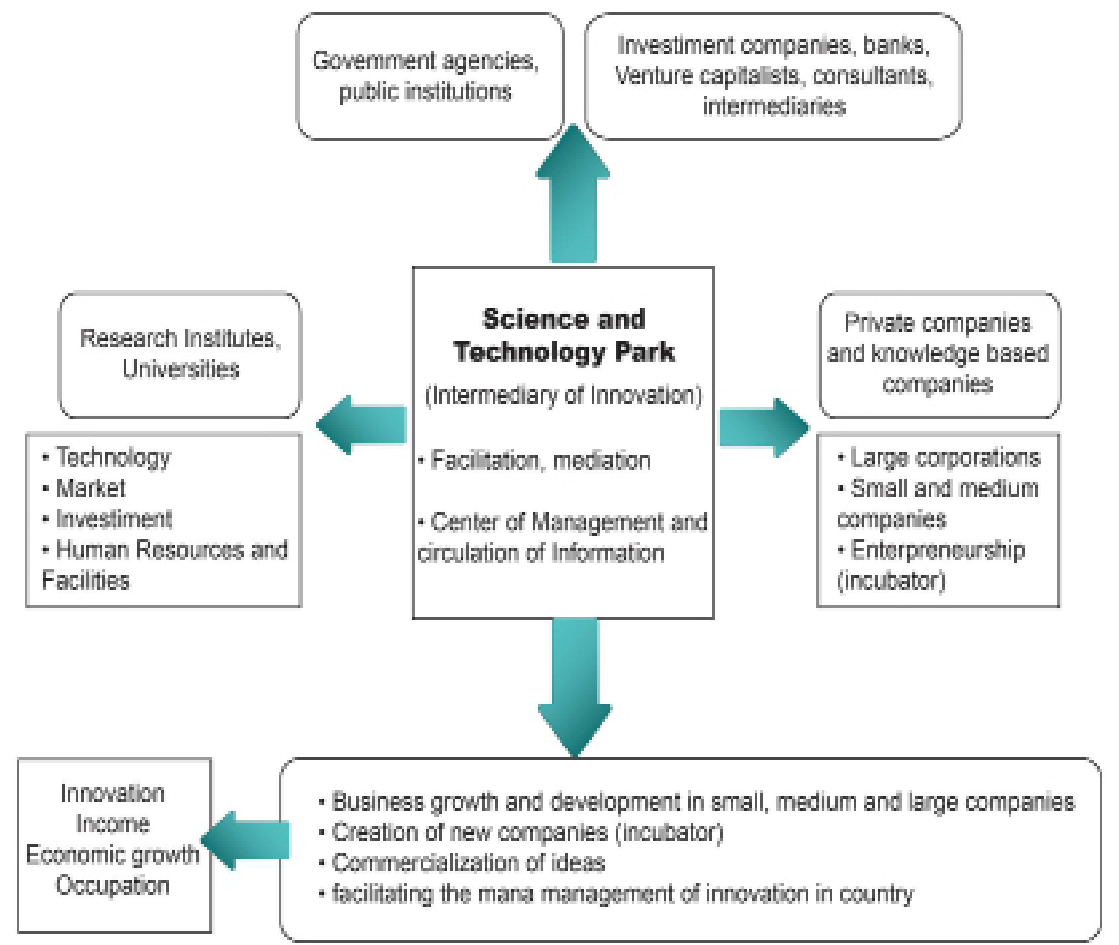

\section{CONCLUSIONS}

TThis research showed that the process-based approach is one of the most important advantages of the STPs of the US universities compared with STP of UT. In fact, not only the main mission of a STP is not just providing a place for locating companies or other physical facilities, but also a headquarter of STP should provide a wide range of services to cover all chains of idea to market. Therefore, the lack of coherent plan to develop ideas and innovative cores, as well as supportive mechanism for growing them are the main barriers for success of the STP of the UT compared with the US STPs. Indeed, the limitation of resources and facilities is a very important negative factor for STPs that affect the companies out puts. In other words, we found that companies located in the high level STPs have better conditions in the market compared with their competitor. Therefore, while the operation costs of companies located in the STPs with the high level of facilities are much more compared with medium level of STPs and even they can locates in the out of the STPs, however, they would prefer to continue their business in the STP.

On the other hand, strong collaboration, clustering, and networking among the companies, headquarter, government and other beneficiaries is an important factor among the STPs of the UT. In contrast, lack of access to information among the UT, STP companies is really a weakness for STP. Fallowing the innovative framework of success for managing and improving the performance of STP is presented by the researchers. 


\section{BIBLIOGRAPHIC REFERENCES}

[1] Nuzir,F. Dewancker, J. (2014). Understanding the Role of Education Facilities in Sustainable Urban Development: A Case Study of KSRP [J]. Procedia Environmental Sciences, Volume 20, 2014, Pages 632-641

[2] McAdam, M. McAdam, R. High Tech Start-ups in University Science Park Incubators: The Relationship Between the Start-up's Lifecycle Progression and use of the Incubator's Resources [J]. Technovation, Volume 28, Issue 5, 2008, Pages 277-290

[3] Martin-Rios, C. Why Do Firms Seek to Share Human Resource Management Knowledge? The Importance of Inter-Firm Networks [J]. Journal of Business Research, Volume 67, Issue 2, 2014, Pages 190-199

[4] Löfsten, H. Lindelöf, L. Science Parks and the Growth of New Technology-based firmsacademic-industry Links, Innovation and Markets [J]. Research Policy, Volume 31, Issue 6,2002, Pages 859-876

[5] Corsaro, D. Ramos, C. Henneberg, SC. Naudé, P. The Impact of Network Configurations on Value Constellations in Business Markets-The Case Of an Innovation Network [J]. Industrial Marketing Management, Volume 41, Issue 1,2012, Pages 54-67 